\title{
Synet på natur og historie hos Grundtvig og Løgstrup
}

\author{
Af Hans Henningsen
}

Det er almindeligt antaget, at der består et slægtskab mellem skabelsessynet hos Grundtvig og K. E. Løgstrup. Og med god grund. Ja, på en måde kunne man være fristet til at betragte hele Løgstrups forfatterskab som en udfoldelse af Grundtvigs »menneske først«. Måske bliver det endda klarere hos Løgstrup, hvad det i grunden vil sige at tale almenmenneskeligt om menneskelivet.

Man genfinder hos Løgstrup mange af de centrale tanker hos Grundtvig. Når Løgstrup f. eks. taler om »interdependens« som menneskeligt grundvilkår, svarer det langt hen ad vejen til Grundtvigs tale om fællesskabet og hans opfattelse af individualismen som en abstraktion. Også tanken om »det folkelige « spiller en afgørende rolle for Løgstrup. Dybest set er det den tanke, som er bærende for det samfundsengagement, der er til stede så at sige overalt i Løgstrups forfatterskab, og som omfatter hele spektret fra miljøspørgsmål og energipolitik over $\varnothing$ konomi og politik $\mathrm{i}$ almindelighed til skole og opdragelsesspørgsmål. ${ }^{1}$ Livet igennem var Løgstrup desuden, i teori og praksis, optaget af højskolen.

Grundtvigs tale om videnskaben, som må være til for livets skyld, og om vekselvirkningen mellem videnskab og folkelig oplysning har ligeledes sin tydelige parallel hos Løgstrup, der ved hjælp af fænomenologiens begreb om »den videnskabelige reduktion « påpeger, hvordan enhver videnskabsgren ved selve sin metode konstitueres som en synsvinkel, hvorunder virkeligheden betragtes, dvs som en begrænsning i forhold til »livet« forstået som totalitet og som praktisk livsvirkelighed. Forbindelsen mellem videnskab og livsverden må følgelig, hvis den overhovedet skal opstå, tilvejebringes i kraft af vekselvirkning. Altså helt i tråd med Grundtvigs tanker om folkelig oplysning.

Yderligere skal nævnes to træk, som peger i retning af en grundtvigsk virkelighedsopfattelse hos Løgstrup. Det ene er tydningen af tilværelsen som en stadig kamp mellem liv og død. Løgstrup formulerer sig herom flere steder i »Skabelse og tilintetgørelse« i direkte tilslutning til Grundtvig. ${ }^{2}$ Det andet er den ejendommelighed, at det formelt etiske hos Løgstrup i stigende grad underordnes talen om »betydning «, som hos Grundtvig: »Livsoplysningen ligger ikke alene 
forud for evangeliets tale, men den ligger også forud for lovens tale. $\ll^{3}$

\section{To dimensioner}

Men ser man nøjere til, er der trods disse fælles træk også væsentlige divergenser. Hvor Løgstrup taler om fænomenerne, naturen og universet, taler Grundtvig om historien, tilmed så radikalt, at det kan være svært at se, hvordan der inden for Grundtvigs virkelighedshorisont overhovedet kan blive plads til det engagement, som for L $\varnothing \mathrm{g}$ strup er det væsentlige. Hertil kommer, at fremtidsperspektivet hos Grundtvig er til stede overalt, mens det hos Løgstrup nærmest er fraværende. Endvidere er hos Løgstrup synet den befriende og hørelsen den forførende sans, mens det er omvendt hos Grundtvig. Ja, sansningen overhovedet opfatter kun tingenes skygge, hævder Grundtvig. Hos Løgstrup derimod er sansningen den befriende og livgivende instans. Og mens Løgstrup taler om kunsten som erkendelse, ser Grundtvig med den største betænkelighed på både maleri og skulptur - som i bedste fald lavere former for kunst. Kun poesien og billedsproget blotter, hvad det sanselige dække skjuler. Tanken synes virkelig at bevæge sig $\mathrm{i}$ to helt forskellige retninger. Man kunne også sige, at der er tale om en tænkning i to modsat rettede dimensioner. At udjævne denne spænding lader sig næppe gøre.

\section{Falles intention}

Men for begges vedkommende må tankegangen naturligvis ses på baggrund af den filosofiske og idéhistoriske situation, hvori opfattelserne er blevet til, hvilket også i nogen grad kan bidrage til en forståelse af, hvorfor tankerne kommer ind i så forskellig baner. Først og fremmest spiller forholdet til transcendentalfilosofien en afgørende rolle.

Grundtvig forsøger aldrig at tage noget virkeligt opgør med Kant, som han egentlig mener at kunne ignorere. I stedet samler han hele sin filosofiske argumentation, som den udfoldes i Danne-Virke-afhandlingerne, om at indsætte historien som eneste kilde til virkelighedstydning, reelt i filosofiens sted. 
For Løgstrup derimod stiller sagen sig anderledes. Han ser, at skal skabelsessynets virkeligheds- og menneskeopfattelse overhovedet kunne forsvares humant, så kræver det et opgør med Kant, hvis erkendelsesteori danner basis for den moderne illusion, at al betydning i historien skyldes menneskenes kulturproduktion. Men dette opgør kan i den efterkantianske epoke, hvori Løgstrup befinder sig, kun foretages filosofisk $i$ form af en fænomenologisk påvisning af noget »før-kulturelt«. Den forudsætning, som hele Grundtvigs historiske syn hviler på, nemlig at der er en betydning i menneskelivet, som ligger i livet selv, er ikke længere umiddelbart til stede, men må så at sige genopdages.

Man kan derfor godt sige, at hvad Løgstrup vil med sin fænomenologi, ja i grunden også med sin metafysik, på en måde er det samme, som Grundtvig ville med historien. Begge taler de om den betydning i det skabte liv, som er givet med livet selv. Hver på sin måde og ud fra hver sit udgangspunkt, historisk stående på hver sin side af Kant.

\section{Grundtvigs filosofiske fundering af billed-og historiesynet}

I Verdenskrøniken af 1812 giver Grundtvig udtryk for en relativt positiv vurdering af Kant. Den kritiske filosofi, mener han på det tidspunkt, kan være en barriere mod vantroen, og derfor bør man egentlig »takke Gud, at han gav os en Kant ${ }^{4}{ }^{4}$ Fem år senere, i Verdenskrøniken af 1817 , har Grundtvig imidlertid skiftet mening. Han har nu indset, at havde Kant ret, måtte konsekvensen være, at alt, hvad han selv forstod ved historisk Vidskab, ville blive en umulighed. Så kunne vi intet vide »uden hvad de sandselige Ting ere, forsaavidt de findes i Tiden og Rummet «. Men samtidig er han kommet til den konklusion, at Kant hører fortiden til. Den kritiske filosofi er allerede passé. $^{5}$

Samtidig ændrer Grundtvig sin vurdering af empirismen, der fra nu af bliver forbundsfællen i kampen mod den idealistiske virkelighedsflugt, som var fulgt i kantianismens kølvand først og fremmest i Tyskland. Det var en fejltagelse, indrømmer Grundtvig nu, når han tidligere som romantikken og idealismen ville skyde skylden for dårskaben og blændværket $\mathrm{i}$ tidens oplysning på erfaringen og den sunde menneskeforstand. Forholdet er tværtimod det, at erfaringen, 
og det vil for Grundtvig sige historien, er og bliver den eneste vej til sand vidskab. ${ }^{6}$

Altså kunne udbygningen af det historisk-poetiske virkelighedssyn fortsættes med støtte i engelsk empirisme og uanfægtet af Kant, hvilket sker i Danne-Virke-afhandlingerne under en udstrakt brug af førkantiansk logik. Ræsonnementet er i store træk følgende:

Fornuften rummer i sig kun »Maalestokken for timelig Sandhed «. Alt indhold må komme fra erfaringen. Den mest fundamentale erfaring, et menneske kan gøre, er erfaringen af sig selv i selvbevidstheden. Men selvbevidstheden er ikke en evig bevidsthed og må følgelig være forårsaget af noget højere, nemlig »den evige Værelse«. Der gives imidlertid ikke nogen umiddelbar erkendelse eller anskuelse af denne, men mennesket må nøjes med at erkende sig selv som billede og alt $\mathrm{i}$ verden som billeder af det evige.

Grundtvig skelner mellem »Kundskab« og »Vidskab«, eller som det også hedder »udvortes « og »indvortes« erfaring. Kun den indvortes erfaring, som opfatter tingene $\mathrm{i}$ deres billedlige betydning, giver historisk vidskab, syn for sagn.

Men vidskaben må hvile på historisk kundskab, og risikoen er derfor, at det bliver ved det udvortes. For med evnen til billedlig opfattelse er det gået ned ad bakke i historien. ${ }^{7}$ Ganske vist var det nyskabte menneske heller ikke fuldkomment. Også det skulle først skue i spejlet stykkevis, indtil det var i stand til at se ansigt til ansigt. ${ }^{8}$ Men de ældste sprog var endnu udprægede billedsprog, hvad det hebraiske sprog efter Grundtvigs opfattelse bærer tydeligt præg af. ${ }^{9}$ Det faldne menneske begyndte imidlertid i stigende grad at tale ubilledligt. Fornuften og sansningen vil nemlig gøre sig fri og gå på egen hånd, og sker det, mister mennesket evnen til at se med det »aandige $\varnothing_{\mathrm{je} \ll}$.

Skal det 19. århundrede nogensinde fortjene navn af »det filosofiske århundrede«, da kan det, hævder Grundtvig, ikke ske blot ved at fordømme det 18. århundrede, men kun ved at gøre, hvad dette undlod. Det må »erkiende Historien for hvad den uimodsigelig maae være: Sandhedens virkelige Aabenbarelse, Menneskets virkelige Udvikling, Roden til, Indbegrebet af og Prøvestenen for al menneskelig Videnskabelighed og dyrke den som saadan med aabent Øie og utrættelig Flid; uden at lade sig indbilde der enten i Natur Betragtningen, umiddelbar Anskuelse eller Sligt kan findes nogen Gienvej til Historiens Maal, der jo umulig kan naaes før Dagenes Ende ${ }^{10}{ }^{10}$ 
Grundtvig tror på en blomstring for den historiske vidskab i det 19. århundrede og bliver ikke mindre optimistisk med tiden. I 1830'erne mener han, at denne historiske anskuelse kan deles af kristne og »naturalister med ånd «. Altså den er forenelig med »menneske først « og kan derfor være det bærende grundlag for den folkelige højskole.

Hele Grundtvigs virkelighedsopfattelse, hans skole- og opdragelsessyn, hans begreb om oplysning og tanker om folkelighed er bestemt af et historiesyn med billedsynet som det centrale element. Det samme gælder Grundtvigs opfattelse af natur og kunst. Men derom senere.

\section{Indfoeldethed}

Siden Grundtvigs tid er der sket et skred i virkelighedsopfattelsen. Subjektet er med Løgstrups udtryk trængt ud »på randen af universet «. ${ }^{11}$ I denne forandring har transcendentalfilosofien med dens dyrkelse af det selvberoende subjekt og opfattelsen af erkendelsen som produktiv sin store andel. Kant repræsenterede altså virkelig en udfordring, som var væsentlig alvorligere end antaget af Grundtvig, og som Løgstrup livet igennem var bestemt af, så at sige i alt hvad han tænkte og skrev.

Den frigørelsesproces, som samfundsmæssigt, moralsk og kulturelt blev det selvberoende subjekts projekt, har, hvad ingen vel vil benægte, haft sine gode sider, men også sine omkostninger. Eller som Løgstrup formulerer det, efterhånden som vor kultur blev en emancipatorisk kultur, satte man sig i stadig højere grad det mål at gøre det, der var nogens, til alles. Det har bidraget til en bedre fordeling af livsgoderne og givet flere mennesker muligheder, som de før ikke havde. Men een ting ligger uden for emancipationens rækkevidde, den kan ikke bidrage til en genvakt sans for det, som er ingens. Elementerne vand, jord og luft er ingens, sproget er ingens og barnet er ingens. Men vi udvinder produktivkræfter af elementerne, overtalelse af sproget og proselytter af barnet. Det, som er ingens, gør vi til nogens eller alles. Men myten insisterer på, at det er ingens. ${ }^{12}$ Det samme gør kunst og filosofi.

En tilsvarende dobbelthed i holdningen til emancipationen finder man hos Grundtvig. Det fremgår tydeligt f. eks. af afsnittene om den franske revolution i Mands Minde. Både Grundtvig og Løgstrup var 
tilbageholdende med i det hele taget at anvende ordet "frig ørelse «. De ønskede i stedet at pege på den frihed, der kommer af sammenhænge, som ikke er skabt af kulturen, men som er givet med livet selv.

Løgstrups bestræbelse går grundlæggende ud på at beskrive menneskelivet som »indfældet « $\mathrm{i}$ sådanne betydningsbærende sammenhænge. Det vil sige sammenhænge, som subjektet ikke suverænt vælger, og som man derfor i epoken har tabt sansen for. De suveræne livsytringer, tilliden og talens åbenhed er eksempler på sådanne givne før-kulturelle strukturer. Andre sammenhænge foreligger i sprog, natur og univers - samt i historien. ${ }^{13}$ Løgstrup tilsidesætter ikke historien, tværtimod, han forsvarer historien.

\section{Lфgstrups forsvar for historien}

Når Løgstrup undertiden kan antyde, at epoken er blevet alt for historisk, så ligger der ikke deri en opfordring til at se bort fra historien eller til at negligere det historiske menneskeliv til fordel for en gåen op i naturen. Tværtimod, meningen er den, at i den epoke, vi tilhører, står mennesket ifølge epokens egen virkelighedsopfattelse tilbage som eneaktør på scenen ${ }^{14}$ med tilsyneladende ubegrænsede handlemuligheder, mens historiens substans - som det for Grundtvig kom an på er gået samme vej som universet og naturen, nemlig ud af synsfeltet. Eller sagt med andre ord, epoken har emanciperet sig ud over, eller op over om man vil, såvel univers som natur og historie til, hvad Løgstrup kalder en »randtilværelse«.

I randtilværelsen er alt - mener epoken selv - op til menneskene, dvs der er ikke andet end historie. Men hvor der ikke er andet end historie, mister historien sin mening. Historien går i opløsning, for der er ingen rigtig historie til uden "som en historie om, hvad det kommer an på og hvad det ikke kommer an på i menneskets tilværelse. Historie som et fænomen-indifferent forløb af begivenheder og handlinger findes ikke. ${ }^{15}$

Disse ord af Løgstrup er i virkeligheden intet mindre end en bekendelse til universalhistorien, modsat epokens rent historistiske historieopfattelse, ifølge hvilken det er historien, der bestemmer, hvad der skal forstås ved fænomenerne. Der er hos Løgstrup een og kun een historie som hos Grundtvig, nemlig historien om, hvad det kom- 
mer an på. At Grundtvig så har andet og mere at sige om denne historie end Løgstrup, er en sag for sig. Også Grundtvigs historiske anskuelse har epoken emanciperet sig fra, og det kan være svært at se, hvordan der kan pustes liv i den igen, helt eller delvist, uden netop i kraft af en genvakt opmærksomhed om, hvad det i historien kommer an på, nemlig menneskelivet, indfældet som det er i natur, historie og univers.

For en skabelsesteologi i moderne sammenhæng bliver opgaven derfor først og fremmest den helt elementære at beskrive de betydningsbærende strukturer i tilværelsen, de fænomener, det kommer an på, således at indsigten er tilgængelig på rent humant grundlag og forståelsen plausibel eller i det mindste diskutabel som en fællesmenneskelig »tilværelsesoplysning $\ll .{ }^{16}$ Dette svarer i princippet til, hvad Grundtvig mente med »menneske først $«$.

Men på den anden side nærede Grundtvig, hvad citatet ovenfor mere end antyder, en betydelig mistænksomhed mod al anden oplysning end netop den historiske, en uvilje mod alt, hvad der ikke var tænkt og erfaret inden for historiens dimension. ${ }^{17}$ Hele den vidtløftige filosofiske argumentation i Danne-Virke-afhandlingerne har jo det formål at demonstrere, at historien er den eneste kilde til sand vidskab.

Løgstrup kommer dog Grundtvig et stykke i møde. Det sker med tanken om, at fænomenerne opstår $i$ historien, og at historien ikke var så historisk, før det ene og det andet fænomen blev til, som den blev bagefter. ${ }^{18} \mathrm{Om}$ det så er indrømmelse nok, får stå hen som et åbent spørgsmål. Grundtvig var ganske radikal, når det gjaldt om at hævde historiens prioritet.

Det blev også bestemmende for hans natursyn.

\section{Grundtvigs natursyn}

Skønt Grundtvig opfatter hele skaberværket som et billede af det evige, menneskelivet så vel som naturens verden, har han alligevel, hvad naturen angår, svært ved at håndtere dette billedsyn i praksis, hvilket tydeligt viser sig i hans poesi, ikke mindst i salmerne.

Grundtvig har det simpelthen bedst med naturen, når han kan anskue den ud fra historien, ja som en del af det historiske menneskeliv. Naturbillederne $\mathrm{i}$ hans salmer og sange er alle hentet fra den 
natur, der hører menneskelivet til, som det findes i dansk sammenhæng, den natur, der er gode danske, jævne, hjemlige ord for. Her er man inden for en sfære, hvor det i en helt anden forstand, end tilfældet er i naturverdenen som sådan, står klart, at det håndgribelige og synlige indgår i en sammenhæng af åndelig art. Både fædrelandsfølelsen, kærligheden mellem forældre og børn og ikke mindre oplevelsen af forbundethed med slægten, der gik forud, overskrider jo det tingslige og rent håndgribelige og er dermed udtryk for den oversanselige virkelighed. ${ }^{19}$ Det er inden for denne menneskeverden, ikke i naturoplevelsen, tilknytningspunkterne er til den religiøse tilværelsestydning og skabelsessynet.

Det er alt andet end naturen i dens vælde og storhed, vi møder hos Grundtvig. Det store i skaberværket er mennesket. Og det er ikke naturen, der fremkalder forundring, men derimod det historiske menneskeliv, mennesket i ordets verden.

Der er i Grundtvigs brug af naturbilleder, frem for alt i salmerne, overhovedet ikke tale om nogen naturoplevelse eller naturerkendelse, som tolkes religiøst. I salmerne tjener naturbillederne kun til at oplyse, illustrere om man vil, det religiøse indhold. Forholdet er et rent udvendigt. Og ofte er distancen tydeligt fastholdt ved brug af ordet »som « - ligesom, f. eks. i salmen »Vidunderligst af alt på jord er Jesu Kristi rige «: »Dets Glans opstaar som Aks i Vang, som Maj i Bøgeskove, ja prægtig under Fuglesang som Gyldensol af Vove «. Der er her intet religiøst ved naturen og intet egentligt forhold mellem naturen og Gudsriget. Og det til trods for at hele skaberværket ifølge Grundtvigs teologiske syn er et billede af det evige.

Undertiden kan det dog se ud, som havde Grundtvig overvundet denne spaltning, f. eks. i pinsesalmen »I al sin Glans nu straaler Solen«. Men tag ikke fejl, advarer Magnus Stevns. Det er ikke den astronomiske sol, der stråler i al sin glans, men »Livslyset over Naadestolen «, i engen risler ikke bækken fra Udby, men »Bæk af livets flod «, og den ånd, som daler, »volder« at det bliver sommer i kristenheden, ikke at det bliver sommer i Danmark. ${ }^{20}$ Misforståelsen kommer af, at der - tilfældigt - er et sammenfald mellem pinsen og Grundtvigs foretrukne naturbilleder, som i særlig grad er hentet fra forårs- og sommertiden, fra lyssiden og tilblivelsessiden af tilværelsen.

Denne distance til naturen bevirker til gengæld, at Grundtvig kan være fuldstændig suveræn i sit valg af naturbilleder. Man finder såle- 
des sommermotiver i julesalmerne, hvor »Blomster gro i Enge«, og »Lærker slaa«, og solen kan stå op på alle tider af døgnet, som det $\mathrm{f}$. eks. sker i gendigtningen af den gamle dagvise, hvor det midt om natten klarer op i østerlid »til dejligste Morgenrøde«.

Det er uden tvivl netop den frihed, Grundtvig tager sig i brugen af naturbilleder, der gør hans sange og salmer så yndede. Han fremhæver med sit billedvalg alt, hvad der rummer liv, fred og tilblivelse.

Til naturen har Grundtvig altså i virkeligheden et dobbelt forhold. Dels anskuer han naturen i konsekvens af billedsynet, dels lægger han en tydelig afstand til naturen. Der er noget hedensk ved naturen. Grundtvig kan direkte omtale naturen som fristelse, hvilket i $\emptyset$ vrigt dementerer en eventuel formodning om, at han ingen sans havde for naturen. Øvede naturen ingen tiltrækning på ham, kunne den næppe heller være nogen fristelse.

Men forholdet er det, at der er en konflikt mellem naturoplevelsen og. det historiske syn. Grundtvig giver selv udtryk for, at han har lettere ved at se det himmelske $\mathrm{i}$ historiens end $\mathrm{i}$ naturens billede. Men ved troens hjælp er øjet dog blevet opladt også for naturen, selv om han må indrømme, at han »aldrig deri skue saa klart« som i historien. ${ }^{21}$

I samme forbindelse, nemlig i en kommentar til digtet »Freias Priis«, hedder det om dette digt: »...seer man vist til, da opdager man, at jeg og min Sang vare paa slemme Veie, at vi stode ved Indgangen ikke til den himmelske, men til den jordiske Skjønheds Rosenlund, hvor det ei klinger sødt fra uskyldig, barnlig Kjærlighed, men smigrende fra kjødelig Lystighed; Var jeg kommet længere end i Dørren, havde disse toner flænget mit Øre, da havde det været ude med min Sangs Betydning..."

Der er noget dæmonisk ved naturen. Den lokker og drager og vil, at tiden skal stå stille, og at man skal blive eet med den, opleve naturen selv som evig og ikke som et billede på det evige.

Naturen omtales hos Grundtvig ofte som død og livløs, og til dyreverdenen lægger han normalt betydelig afstand. Om dyr bruges gennemgående ret negative udtryk med en enkelt undtagelse, nemlig fuglene. Fuglesangen er egentlig den eneste rene sanseoplevelse, Grundtvig er helt tryg ved. »Hvergang Fuglen synger os over Hovedet, da er det som om den følde, og ville minde os om at i Mennesket er det store Møde kommet i Stand, og at der skal den hellige Gien-Forening gaae for sig ${ }^{22}{ }^{22}$ Fuglens sang vidner om, at der er 
noget foroven, »herligere end Alt under Himmelen«. Uforklarlig er sangen, mener Grundtvig, uden som »en Gienlyd af Skaberens Bliv, af det Guddoms-Ord, der giennemstrømmer Skabningen, sidder som fangen i Malm og Steen, men rører sig levende i Fuglens og Menneskets Bryst «. ${ }^{23}$

\section{Naturopfattelsen hos Løgstrup}

Vender vi os nu til Løgstrup, så finder man ikke her nogen tilsvarende spaltning eller dobbelthed i natursynet. Heller ikke noget forbehold over for sanseoplevelsen, tværtimod. Sansningen er livgivende. Og som sagt, der er byttet om på rangforordningen mellem syn og hørelse. Synet er den befriende sans, hørelsen den forførende. Virkeligheden er ikke mere kun historisk, men der er også en anden, tværgående dimension, kendetegnet ved ord som »fænomen«, »natur« og »univers «.

Det er ganske vist stadig historien, der er det basale, som det selvfølgelig må være tilfældet i enhver skabelsesteologi. »Kosmos har historie «. ${ }^{24}$ Men det betyder ikke, at der ikke også er en historie, som foregår på universets betingelser. Der er, om man så må sige, to dimensioner, som må respekteres i deres forskellighed, men som på ingen måde er uforenelige modsætninger, historie og univers.

Udtrykket »univers « kan i øvrigt let misforstås i retning af det naturvidenskabelige begreb om univers. Men hos Løgstrup betegner ordet først og fremmest det ikke kulturskabte, det, som ikke kan tilskrives kulturen eller samfundet, f. eks. de suveræne livsytringer eller den ejendommelighed, at tilværelsen har eengangskarakter, og at typen går igen varieret $\mathrm{i}$ eksemplarerne, den »analoge orden«. Da disse træk eller ejendommeligheder ikke kommer fra kulturen eller samfundet, er der ikke andre muligheder tilbage end at sige, at så må de komme fra universet. De gør sig i øvrigt ikke kun gældende i mennesketilværelsen, men også i naturen.

Det er ikke den type invarianser, naturvidenskaberne almindeligvis interesserer sig for. Hvad Løgstrup koncentrerer sig om, er noget meget mere simpelt, noget, der er umiddelbart tilgængeligt for den almindelige erfaring og sunde menneskeforstand, som Grundtvig nok ville udtrykke det. 
Og hvad mener så Løgstrup med »natur «? Det får man et relativt præcist indtryk af et sted i »Skabelse og tilintetgørelse«, hvor han omtaler Harry Martinsons digt om rumskibet Aniara, der under en transport af passagerer bort fra jorden, som menneskene har gjort ubeboelig, kommer ud af kurs og fortsætter ud i rummets uendelighed som en kunstig lille klode. Men derude truer vanviddet. I det endeløse rums ufattelige stumhed bliver erindringen om den verden af lyd, hvori man levede på jorden, en ufattelig fryd, vindens susen, bølgernes brydning over strandens stene, grenene, der knækkes under dyrets flugt. I rumskibet derimod er hvert værelse kun fyldt af ekkoet af deres eget liv. Ord som tom, øde, ubevægelig, stivnet, stum - først nu passer de. De blev misbrugt dengang, de blev brugt om bjerg, $s \varnothing$ og landskab.

Hvad der er legeme, fortsætter Løgstrup, er for lifligt til at kunne kaldes tomt, $\varnothing$ de, ubevægeligt, stivnet. Brændslet til sjælens ild er alle tings sansbare legemlighed. Så selvfølgeligt er det, at hvad sindet i den mest elementære forstand lever af, betænker vi mindst. Men hvert øjeblik lever vi af, at vort sind oplades af den legemlighed, vi er indfældet i. For passagererne i Aniara er det pludselig ikke selvfølgelighed, men et under, en herlighed, de for altid har lagt bag sig, jorden og dens legemlige liv.

Den natur, Løgstrup taler om, er altså heller ikke naturen i dens uendelighed, men - ikke så forskelligt fra Grundtvig - den natur, der hører til menneskelivet og er en eksistensbetingelse for menneskene.

Den måske stærkeste tendens i vor tilværelse, hedder det videre hos Løgstrup, er tendensen til at være ren og skær ånd. Når den tendens ikke sejrer skyldes det alle tings legemlighed, der i sansningen strømmer ind til os. Ondskab er ånd uden legeme. Ondskaben er en tilintetgørende magt, og det er legemligheden, der skal tilintetgøres. ${ }^{25}$

Ånd uden legeme står også for Grundtvig som noget negativt. Legemligt og åndeligt er ikke modsætninger som sandhed og løgn. De lader sig forbinde med hinanden i venlig vekselvirkning, og det forudsætter både en fælles virkelighed og en fælles oprindelse. ${ }^{26}$ Men det er hos Grundtvig først og fremmest »ordet«, der forbinder ånd og legemlighed. Hos Løgstrup er det sansningen.

Man kan vel ikke her tale om nogen uovervindelig modsætning, men netop fremhævelsen af sansningen hos Løgstrup føjer alligevel 
noget væsentligt til og gør forståelsen af det skabte i dets legemlighed mere konkret.

\section{Kunstsynet}

Intet demonstrerer tydeligere den eksklusivt historiske virkelighedsopfattelse hos Grundtvig end netop hans kunstsyn.

Det ældste kunstværk er verden og mennesket. Herfra åbner tiden sig for os som et stort skoleår, hvor der ikke skal læres noget nyt, men hvor kunstværket skal lære at forstå sig selv, og begribe sig selv i Gud. Dertil tjener den historiske vidskab. Ja, i Guds øjne gælder intet andet studium for videnskabelighed end det historiske. ${ }^{27}$

Den største menneskekunst, Grundtvig kan forestille sig, er derfor ikke nogen af de sædvanlige kunstarter, men opdragelsen. Under en omhyggelig opdragelse skal hele historien blive genstand for den enkeltes erfaring. Opdragelsen er den ægte menneskekunst og den er stedet, hvor kunst og vidskab mødes. Barnet afbilder i sin udvikling, svagere eller stærkere, hele menneskeslægtens liv. ${ }^{28}$

Blandt kunstarterne står poesien højest. Men højere endnu står san-

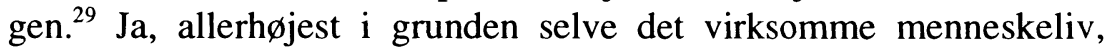
når det leves poetisk, dvs falder ind i det kunstværk, som verden er: »Dag og Daad er Kæmperim«.

Maleri og skulptur derimod har Grundtvig gennemgående kun nedsættende bemærkninger tilovers for, dels på grund af at disse kunstarter er ordløse, dels fordi de, især skulpturen, udelukker forandring og bevægelse, dvs historien.

Løgstrup mener i modsætning til Grundtvig, at det først og fremmest er sanseelementet $i$ kunsten, der stemmer sindet til at sprænge den begrænsning, som den tilvante forståelse af verden er. Og sanseelementet kan være rendyrket som i musikken og det abstrakte maleri. I det stemte indtryk er vi åbne for en forståelse, der går ud over eller bag om vor umiddelbare fortrolighed med tingene.

Den abstrakte kunst kunne Grundtvig af gode grunde ikke udtale sig om. Man kan kun gætte på, hvordan han havde reageret, om han havde kendt den. Det lå tungt nok med den kunst, han kendte. Sansningen vurderede han ikke højt, og slet ikke det rendyrkede sanseelement. Med een undtagelse, nemlig lyden, først og fremmest fugle- 
sangen, der kalder på poesien. Lydene synes i det hele taget at spille en fremtrædende rolle i Grundtvigs naturbeskrivelser. ${ }^{30}$

Men det er et meget mere omfattende og grundlæggende begreb om sansning, Løgstrup bygger sin kunstopfattelse på. Grundtvigs virkelighedsopfattelse er og bliver eet med historiens dimension. Da alt i verden er skabt af en Gud »udi tiden«, er det naturligt, at alt i verden må nævnes og beskues som en gerning, hedder det $\mathrm{i}$ Verdenskrøniken, 1814. På hebraisk er verbet da også roden, ikke navneordet. Navnet er »Gierningens Søn, udsprunget i den af Guds Billed, ligerviis som Sønnen fra Evighed af ved Aanden er født af sin Fader. $\ll^{31}$

At opfatte sansningen som en gerning og verden som »tilsanset « skulle dog også være muligt, og dette er faktisk, hvad Løgstrup gør.

Hvad angår de her behandlede divergenser mellem Grundtvig og Løgstrup, kunne man selvfølgelig overveje, om Løgstrups udtryk »forenende modsætninger « måske var på sin plads, men det må i så fald huskes, at forenende modsætninger just forenes i kraft af en spænding, som ikke kan harmoniseres bort. At modsætninger eksisterer, udelukker imidlertid ikke, at to opfattelser kan være nært beslægtede og i virkeligheden udtryk for en fælles intention.

\section{Noter og henvisninger}

1 Jf. »Kære Hal - Kære Koste«, 1992, s. 111, hvor Løgstrup over for Hal Koch hævder præstens - og universitetslærerens pligt til at gøre et folkeligt arbejde.

2 Jf. Skabelse og tilintetgørelse, 1978, s. 55 og 279.

3 Skabelse og tilintetgørelse, s. 249.

4 Kort Begreb af Verdens Krønike, 1812, s. $257 \mathrm{ff}$.

5 Udsigt over Verdens-Krøniken, 1817, s. 554 ff.

6 Om Videnskabeligheds Forhold til Erfaring og sund Menneske-Forstand, Danne-Virke III, s. 21 ff.

7 Om Aabenbaring, Konst og Vidskab, Danne-Virke III s. 259. 


\section{5}

8 Kort Begreb af Verdens Krønike 1814, s. 16.

9 s. $183 \mathrm{f}$.

10 Om det philosophiske Aarhundrede, Danne-Virke I, s. 129.

11 Ophav og omgivelse, s. 30.

12 S. $187 \mathrm{f}$.

13 s. $201 \mathrm{f}$.

14 s. 14.

15 s. 164.

16 Løgstrup anvender dette udtryk flere steder, f. eks. i essayet »Skolens formål«, Solidaritet og Kærlighed, 1987, s. 44 ff.

17 Det er heller ikke tilfældigt, mener Grundtvig, at det hebraiske sprog, der jo for ham stod skabelsesforståelsen langt nærmere end noget andet sprog, ikke har nogen særlig tid for præsens. VK 1814, s. 191.

18 Ophav og omgivelse, s. 165.

19 Om Mennesket i Verden, Danne-Virke II, s. 192. Om Aabenbaring, Konst og Vidskab, Danne-Virke III, s. 276.

20 Magnus Stevns: Fra Grundtvigs Salmeværksted, 1950, s. 52.

21 Kvædlinger, 1815, s. 138.

22 Om Aabenbaring, Konst og Vidskab, Danne-Virke III, s. 167.

${ }^{23}$ Om Mennesket i Verden, Danne-Virke II, s. $161 \mathrm{f}$.

24 Det uomtvistelige, 1984, s. 69.

25 Skabelse og tilintetgørelse, s. 42 ff.

26 Jf. Om Videnskabeligheds Forhold til Erfaring og sund Menneske-For stand, Danne-Virke II, s. 39. 


\section{6}

27 Om Aabenbaring, Konst og Vidskab, Danne-Virke III, s. 260.

28 s. 269 f.

29 s. 266 f. og 274 f.

30 Jf. C.I. Scharling: »Naturfølelsen hos Grundtvig« i »Kirken og det humane Aandsliv«, 1927, s. 82 f).

31 Kort Begreb af Verdens Krønike, 1814, s. 191. 
Gammel nok jeg nu er blevet Mellem Vugge min og Grav, $\mathrm{Nu}$ jeg staaer paa Falderebet Ved det store, vilde Hav, Hvor Magneten er Guds-Ordet Og Guds Aand staaer selv ved Roret.

Stormene er frygtelige

Stille staaer her Mandevid, Nærmest er de Dødes Rige Nemt det er at stævne did, Men o vee for Uglesangen Bundløs der er Undergangen.

Vel, paa jordisk Viis at regne Langt af Led er Paradis Er os nært dog allevegne Hvor hos Ordet er Guds Priis, Saa for Sjæle-Færge-Stavnen Brat sig aabner Himmel-Havnen!

Ja, hvor Aanden staaer for Styret, Og Guds-Ordet er Kompas, Giælder, som i Eventyret, Evighedens Time-Glas, Der sig brat, som sagt, saa gjort Aabner Evighedens Port.

Derfor Jesus-Christus-Navnet

Prises skal evindelig,

Af hans Kiærlighed omfavnet, Hjertet er i Himmerig, Naar med denne Verden brydes, Til Guds-Bordet vi indbydes! 